\title{
THE RELATION OF THE AMOUNT OF TAIL RE- GENERATED TO THE AMOUNT REMOVED IN TADPOLES OF RANA CLAMITANS ${ }^{1}$
}

\author{
BY \\ MAX MAPES ELLIS \\ With Three Figures \\ INTRODUCTION
}

The experiments furnishing the data employed in these observations were made at the Zoölogical Laboratory of Indiana University at Bloomington, during the years 1907-I908, on tadpoles of Rana clamitans (Latreille), and are a detailed study of a problem presented in the Biological Bulletin, April, I908. In this report it was stated that, "the rate of regeneration varies not only directly but proportionally with the distance the cut is removed from the tip of the tail." This proportional relation was between the length of the part of the tail removed and that regenerated at the end of twelve days. The present experiments ascertained the relation between the amount removed and that regenerated at various intervals throughout the period of regeneration under several sets of conditions. The results may be stated in brief as follows:

I After a certain percentage of the amount removed had been regenerated, regeneration ceased entirely. (This percentage was always less than one hundred.)

2 The same percentage of the part removed was regenerated by all tadpoles maintained under uniform conditions and of the same age, whether the amount removed was large or small; that is, the amount of regeneration at the time regeneration ceased was proportional to the amount removed.

1 Contribution from the Zoölogical Laboratory of Indiana University, No. 106.

The Journal of Experinental Zoölogy, vol. vil, no. 3 . 
3 The time elapsing between the operation and the cessation of regeneration varied with the amount removed.

4 The amount regenerated throughout the regeneration period was influenced by temperature.

The only regeneration considered was that of the tail; hence the term "regenerated" refers to the regenerated tail. The comparison made was that of length, the length of the regenerated part being compared with the length of the part removed.

\section{FACTORS INFLUENCING REGENERATION}

Throughout the experimentation an effort was made to consider all of the factors which might influence the amount of regeneration. These were generally controlled directly, but if this were impossible, they were reduced to a constant by the introduction of a "control series" of uninjured tadpoles whose reactions to the factors of the experiment were noted. The factors of largest importance are here considered.

I Environment. The animals were kept in glass berry dishes containing about $15^{\circ}$ cubic centimeters of water. These were of a uniform size and shape allowing each individual equal freedom and air. The dishes were covered with panes of window glass so arranged as to permit the free circulation of air between them and the top of the dishes. In Experiments 2 and 3, the groups of tadpoles were kept in large glass battery jars.

2 Food. Three kinds of food were used: fresh Spirogyra, raw beef and a combination of both. Some series were not fed at all. When Spirogyra was used, more was placed in the dishes than would be eaten before the next feeding time, so that there would be an excess of food always present. As the food was not the same for all experiments, that given in each case is stated at the beginning of the record of the experiment.

3 Temperature The temperature in Experiments I, 4, and 9, was not controlled directly, but the average temperature of the water in the dishes was taken as a standard temperature for the experiments. The remaining experiments were subjected to definite temperature conditions. The jars containing the tadpoles 


\section{Amount of Tail Regenerated to Removed in Tadpoles 423}

of Experiments 2 and 3 were almost submerged in water of a known temperature which transmitted a very constant amount of heat to the water within the jars. The dishes in which Experiments 6 and ro were conducted, were placed in a chicken incubator; and those of Experiments 5, 7, and 8, in a chicken brooder. Both incubator and brooder gave very constant temperatures by means of their automatic temperature regulators.

4 Light Light was taken as a constant in these experiments as both the brooder and incubator had glass doors which allowed the animals within them the same light as those kept upon tables in the room. No animal received direct sunlight.

5 Age There was no definite way of obtaining the absolute age of any of the tadpoles except those used in Experiment ro, which were hatched from the eggs in the laboratory. Because of this fact, body length and tail length were used as units in the determination of the relative ages of the various individuals. It was assumed that tadpoles of the same species, collected from the same part of a given pond, and of the same body measurements were of about the same age. There must, of course, be some exceptions to this calculation of age; but the uniformity of results and data show that there was probably little error from this source.

6 Individual Variation The effect of individual variation was eliminated as far as possible by the use of large numbers of tadpoles. The deviation of any one animal from the mass is easily noted from the individual data.

\section{NATURE OF OPERATION AND MEASUREMENTS}

The method of removing a part of the tail was the same for all animals used. A tadpole to be operated upon was placed on a smooth block of parraffine with its tail evenly spread and the body covered with a piece of wet cloth. The amount to be removed was then measured with dividers and the cut made at right angles to the notochord by a single stroke of a razor. Only those animals with a clean even cut were used. In determining the amount to be removed the measurements were always made from the tip of the 
tail cephalad. The piece removed was immediately measured under a microscope with an ocular micrometer and the exact amount removed ascertained. The measurements of the regenerated parts were also made with an ocular micrometer, the living tadpole being placed upon a glass slide. The body length and tail length were taken with dividers and a steel rule.

The significance of certain terms used is as follows:

"Amount removed" is the length, in millimeters, of the part of the tail removed.

"Amount regenerated" is the length, in millimeters, of the part regenerated.

"Per cent regenerated" is the per cent of the amount removed.

\section{DESCRIPTION OF EXPERIMENTS}

\section{Preliminary Experiment ${ }^{2}$}

The results of this experiment were mentioned in the introduction of this paper as pointing out the present problem. The table of averages is repeated here. The term "rate of regeneration" refers to the amount regenerated in millimeters, divided by the number of days during which the regeneration occurred. This rate of regeneration divided by the amount, in millimeters, removed gives the quantity termed "proportional rate."

TABLE I

$\begin{array}{ccc}\text { AMOUNT } & \text { RATE OF } & \text { PROPORTIONAL } \\ \text { REMOVED } & \text { REGENERATION } & \text { RATE } \\ m m . & m m . & m m . \\ 7 & 0.24 & 0.034 \\ \text { I0 } & 0.34 & 0.034 \\ 13 & 0.43 & 0.033 \\ 7 & 0.19 & 0.027 \\ \text { I0 } & 0.26 & 0.026 \\ 13 & 0.34 & 0.026\end{array}$

This table shows that the absolute rate varied with the amount removed, and that this variation was proportional to the amount removed. Two sets of tadpoles were used; hence the two divi- 
Amount of Tail Regenerated to Removed in Tadpoles 425

sions of this table. The average body length of the animals used in this experiment was 40 millimeters. The measurements were made on the twelfth day after the operation.

\section{Experiment I. Temperature, $74^{\circ} \mathrm{F} . \quad$ Food, Spirogyra}

Sixty tadpoles, body length $37^{-42} \mathrm{~mm}$., were divided into three series-A, B, and C, - of twenty individuals each. The injury given Series A was the removal of $7 \mathrm{~mm}$. of tail; Series B, Io $\mathrm{mm}$.; Series $\mathrm{C}, \mathrm{I} 3 \mathrm{~mm}$. This experiment was maintained under the same conditions as the preliminary experiment just mentioned, which it was intended to duplicate. Twelve days after the operation, the amounts of regeneration were measured. The average amounts regenerated are given in Table 2.

TABLE 2

\begin{tabular}{|c|c|c|c|}
\hline & $\begin{array}{l}\text { AMOUNT } \\
\text { REMOVED }\end{array}$ & $\begin{array}{c}\text { AMOUNT } \\
\text { REGENERATED }\end{array}$ & $\begin{array}{c}\text { PER CENT } \\
\text { REGENERATED }\end{array}$ \\
\hline Series A. & $\ldots$ & 2.66 & $3^{8}$ \\
\hline Series B & .. 10 & 3.68 & 37 \\
\hline Series C. & $\ldots 13$ & 4.81 & 37 \\
\hline
\end{tabular}

The per cent regenerated by each series during the twelve days of this experiment was approximately the same, although the amount removed in each case was different; that is, the length of the regenerated part was proportional to the amount removed. This experiment confirms the preliminary experiment as regards proportional regeneration, but it is obviously incomplete, since $\mathrm{i}$ states the relation between the amount removed and that regenerated at but one time after the operation, namely the twelfth day.

\section{Experiment 2. Food, Spirogyra and Raw Beef}

This experiment was designed to ascertain the relation between the amount removed and that regenerated at some other time than the twelfth day after the operation. The effect of temperature on the amount of regeneration was also noted.

One hundred and sixty tadpoles, body length 37 to $42 \mathrm{~mm}$., were placed in four large glass battery jars, forty in each jar. These 
four jars (designated as Series D, E, F, and G) were kept at the following temperatures:

DEGREES F.

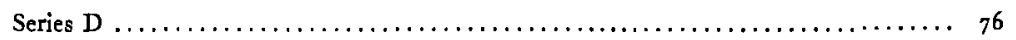

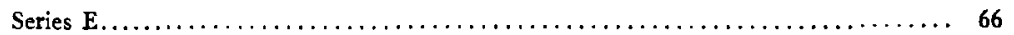

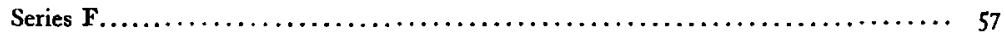

Series $G \ldots \ldots \ldots \ldots \ldots \ldots \ldots \ldots \ldots \ldots \ldots \ldots \ldots \ldots \ldots \ldots \ldots \ldots \ldots \ldots \ldots \ldots \ldots \ldots \ldots,{ }_{47}$

Ten tadpoles in each series were left uninjured, while the remaining thirty were operated upon thus: $2 \mathrm{~mm}$. were removed from the tails of ten; $5 \mathrm{~mm}$. from another ten; and $10 \mathrm{~mm}$. from a third ten. At the end of five days the animals of Series D showed a distinct regeneration; accordingly, measurements of all the series were taken. No attempt was made to keep individual records, but the measurement of every animal in each series was used in computing the averages.

Series $\mathrm{F}$ and $\mathrm{G}$ ( 57 and $47^{\circ} \mathrm{F}$.) showed no regeneration at the end of this first five days. The wounds were healed and the animals as active as when first collected, but there was no new tissue to be measured. On the other hand, however, both Series $\mathrm{D}$ and $\mathrm{E}$ had regenerated. The average regenerations are given in Table 3 .

TABLE 3

\begin{tabular}{|c|c|c|c|c|c|c|}
\hline & \multirow{2}{*}{$\begin{array}{l}\text { TEMPERA- } \\
\text { TURE } \\
\text { DEGREES F. }\end{array}$} & \multirow{2}{*}{$\begin{array}{l}\text { AMOUNT } \\
\text { REMOVED }\end{array}$} & \multicolumn{2}{|c|}{5 DAY REGENERATION } & \multicolumn{2}{|c|}{ I2 DAY REGENERATION } \\
\hline & & & Amount & Per Cent & Amount & Per Cent \\
\hline \multirow{4}{*}{ Series D. . } & & $m m$. & $m m$. & & $m m$. & \\
\hline & 76 & 2 & 1.0 & 50 & 1.0 & 50 \\
\hline & 76 & 5 & 1.8 & $3^{6}$ & 2.5 & 50 \\
\hline & 76 & 10 & 2.4 & 24 & 4.9 & 49 \\
\hline \multirow{3}{*}{ Series E...... } & 66 & 2 & 0.7 & 35 & 0.7 & 35 \\
\hline & 66 & 5 & 0.8 & I6 & 1.7 & 34 \\
\hline & 66 & 10 & 1.0 & Io & 3.2 & $3^{2}$ \\
\hline \multirow{3}{*}{ Series F... } & 57 & 2 & 0 & o & $\circ$ & 0 \\
\hline & 57 & 5 & $\circ$ & 0 & 0 & 0 \\
\hline & 57 & 10 & o & o & - & 0 \\
\hline \multirow{3}{*}{ Series G.. } & 47 & 2 & $\circ$ & $\mathbf{o}$ & $\circ$ & $\circ$ \\
\hline & 47 & 5 & 0 & 0 & 0 & 0 \\
\hline & 47 & 10 & 0 & $\circ$ & $\circ$ & 。 \\
\hline
\end{tabular}


From these averages it is to be seen that the relation of the amount regenerated to that removed is clearly not a proportional one at the end of five days, as was the case at the end of twelve days in Experiment I. All of the series were continued until the twelfth day after the operation, a second set of measurements being taken at that time. Series $F$ and $G$ again showed no regeneration. All of the tadpoles in these two series were still as active as any of the others in the experiment, but the condition of the tail externally was precisely the same as when observed on the fifth day. There were no deaths in any of the series during the twelve days they were maintained and the general health of all the tadpoles seemed good. As all of the other conditions of the experiment were the same for Series F and G as for Series D and E, which did regenerate, this lack of regeneration was ascribed to the effect of temperature upon the processes producing regeneration.

Series $\mathrm{D}$ and $\mathrm{E}$ both made accretions to the amount regenerated during the seven days intervening between the fifth and the twelfth, excepting the first set in each series from which but two millimeters had been removed, which remained constant. As was noted in Experiment I, the per cent regenerated by the various sets of each series during the twelve days was approximately the same, showing the amount regenerated to be proportional to the amount removed at the end of the twelfth day. The per centum regenerated, however, was not the same in Series D as in Series E, the latter being about fifteen per cent less than the former. This difference was evidently due to the lower temperature at which Series E was kept, as the other factors were the same. Three things are evident from the data of Experiment 2. (I) Temperature affects the amount of regeneration, other factors being constant. (2) There is a temperature limit below which tadpoles live but do not regenerate the tail. (3) The percentage of regeneration is not proportional at all times throughout the period of regeneration. Measurements of the control series show that the tadpoles did not grow during this experiment. 
Experiment 3. Food, Spirogyra and Raw Beef

Some months after the conclusion of Experiment 2, another set of tadpoles were subjected to the same conditions used in Experiment 2. Two other series at temperatures not used in Experiment 2 were added. One of these was maintained at $96^{\circ} \mathrm{F}$. and the other at $103^{\circ} \mathrm{F}$. Table 4 is made up from the data collected in this experiment. The measurements were taken but once, the twelfth day after the operation.

TABLE 4

\begin{tabular}{|c|c|c|c|c|}
\hline & $\begin{array}{c}\text { TEMPERA- } \\
\text { TURE } \\
\text { ' F. }\end{array}$ & $\begin{array}{l}\text { AMOUNT } \\
\text { REMOVED }\end{array}$ & $\begin{array}{l}\text { AMOUNT } \\
\text { REGENER- } \\
\text { ATED }\end{array}$ & $\begin{array}{l}\text { PER CENT } \\
\text { REGENER- } \\
\text { ATED }\end{array}$ \\
\hline \multirow{4}{*}{ Series $\mathbf{H}$. . } & 66 & $m m$ & $m m$ & 20 \\
\hline & 66 & 5 & 0.6 & $3^{2}$ \\
\hline & 66 & 10 & 3.0 & $3^{2}$ \\
\hline & 76 & 2 & 0.9 & 45 \\
\hline \multirow{2}{*}{ Series $\mathrm{J} \ldots \ldots \ldots \ldots \ldots \ldots \ldots \ldots \ldots \ldots \ldots \ldots \ldots$} & $7^{6}$ & 5 & 2.2 & 44 \\
\hline & 76 & 10 & $4 \cdot 5$ & 45 \\
\hline Series $\mathbf{K} \ldots \ldots \ldots \ldots \ldots \ldots \ldots \ldots \ldots \ldots \ldots \ldots$ & 57 & \multirow{4}{*}{\multicolumn{3}{|c|}{$\begin{array}{l}\text { all animals active; no deaths; no regenera- } \\
\text { tion. } \\
\text { all animals active; no deaths; no regenera- } \\
\text { tion. } \\
\text { all animals dead in } 24 \text { hours after opera- } \\
\text { tion. } \\
\text { all animals dead in less than I } 2 \text { hours } \\
\text { after operation }\end{array}$}} \\
\hline Series $\mathbf{L} \ldots \ldots \ldots \ldots \ldots \ldots \ldots \ldots \ldots \ldots \ldots \ldots \ldots \ldots$ & 47 & & & \\
\hline Series $\mathbf{M} \ldots \ldots \ldots \ldots \ldots \ldots \ldots \ldots \ldots \ldots$ & 96 & & & \\
\hline Series $\mathbf{N} \ldots \ldots \ldots \ldots \ldots \ldots$ & 103 & & & \\
\hline
\end{tabular}

It was hoped that tadpoles would live at a temperature higher than $76^{\circ} \mathrm{F}$. but unfortunately, the two temperatures above 76 were too high to sustain life. There is the same proportional relation between the amount removed and the amount regenerated at the end of the twelfth day, as shown by these data as has been previously noted. The per cent regenerated in this experiment was lower than that regenerated in Experiment 2, which shows a variation at some point between the conditions controlling the two experiments. A possible cause of this difference may be the influence of the season upon tadpoles' ability 
to regenerate; for the animals used in Experiment 3 were collected in February, while those used in Experiment 2 were taken early in December.

\section{Experiment 4. Food, Spirogyra. Temperature, $7^{80} \mathrm{~F}$.}

In this experiment the relation between the amount removed and that regenerated was obtained every third day throughout the period of regeneration.

Five series, $\mathrm{O}, \mathrm{P}, \mathrm{R}, \mathrm{S}$, and $\mathrm{T}$, were established, twenty tadpoles in a series, body length 37 to $42 \mathrm{~mm}$.; and a control series of forty other uninjured tadpoles arranged. Series $\mathrm{O}$ was injured by the removal of three $\mathrm{mm}$. of tail from each individual; Series $\mathrm{P}$, $5 \mathrm{~mm}$.; Series R, ro mm.; Series S, $15 \mathrm{~mm}$.; and Series T, $20 \mathrm{~mm}$. The regenerated part was measured every three days and the whole experiment maintained for thirty two days. Individual records of the amount regenerated by each tadpole were kept. (See Tables 9, I0, I I, I2, and I3. Also Fig. I.)

It was found that Series $T$ behaved differently from the other series of this experiment, accordingly it is considered separately. At the end of the first three days after the operation, almost half of the tadpoles in Series $T(20 \mathrm{~mm}$.) were dead, and those living were sluggish and weak. The survivors had not regenerated any of the lost tail, the wound not being even healed over in several cases. By the end of the sixth day, seven more of this series had died and the death of another individual on the eighth day reduced the number of living to four. These four continued to live and each one regenerated a part of the removed tail. This regenerated tail, however, was not normal, being twisted and very irregular of outline. It is evident that with a death rate of 80 per cent and abnormal regeneration by those four surviving the operation, the injury was too severe in Series T. The final amount regenerated by the four survivors of this series averaged 20 per cent of the amount removed.

The average regeneration of the four remaining series on the third day after the operation were: 


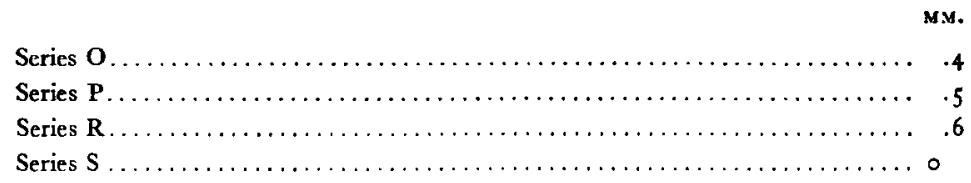

The differences between these amounts are slight, but subsequent observation shows them to be significant. The relation between the amount regenerated at this time and the amount removed is not a proportional one. The series of particular interest at this time is Series $S$ ( $15 \mathrm{~mm}$.) which had no measurable regeneration at the end of the third day. The regeneration of this series was recorded as zero because the amount regenerated was too small to be accurately measured; there was, however, regeneration present at the end of the third day, as in most cases a distinct film of new tissue was visible. All of the wounds were healed at this time. By consulting Table 13 , the amount of regeneration can readily be followed.

All of the series, including Series $\mathrm{T}$, had definite regeneration at the end of the sixth day. These amounts were arranged according to the amount removed, although not proportional to it. The ninth day measurements bear the same relation to each other, that is, the amount regenerated varied in the same direction as the amount removed, but was not proportional to it. The ninth day percentages, however, were distinctly nearer the same than those of the third or sixth day. This places the relation of the amount regenerated to that removed, much nearer the proportional. The amount regenerated by Series $\mathrm{O}$ at this time was $\mathrm{I} .4 \mathrm{~mm}$., 44 per cent of the amount removed. Subsequent measurements show that this series never regenerated beyond this per cent, which remained constant throughout the remainder of the experiment. On the twelfth day Series $\mathrm{P}$ also ceased regenerating, its final amount of regeneration being $2.3 \mathrm{~mm} ., 44$ per cent of the amount removed. Thus, on the twelfth day after the operation, two of the series, $\mathrm{O}$ and $\mathrm{P}$, had reached a limit of regeneration, which was proportional to the amount removed. The other two series, $R$ and $S$, although not having regenerated the same percentage as that regenerated by Series $\mathrm{O}$ and $\mathrm{P}$, were not far below it. The 
next series to cease regeneration was Series $R$, on the fifteenth day after the operation. The final amount regenerated by it was $5 \mathrm{~mm}$., 48 per cent of the amount removed. Series $\mathrm{S}$ stopped regenerating on the eighteenth day with an amount of 7.2 mm., $4^{8}$ per cent of the amount removed. From the eighteenth day until the close of the experiment all of the series remained constant and did not regenerate beyond the limit they first reached. Because of this fact, the curve for all of the series from this time on are straight lines parallel to the base of the plot.

An examination of Fig. I shows each curve to be composed of four distinct regions. The first, one of slow regeneration, lasts for the first three days after the operation; a second, of rapid regeneration, which is of several days' duration; a third, of regeneration distinctly slower than that of the second region; and a fourth, in which the regeneration gradually ceases. At the end of the fourth region, the regeneration probably ceases entirely; although, there is some evidence of very slight regeneration for many days after the apparent cessation of regeneration. The average amounts regenerated by the various series up to the time when regeneration ceased, are to be found in the following table:

TABLE 5

\begin{tabular}{|c|c|c|c|}
\hline & $\begin{array}{l}\text { AMOUNT } \\
\text { REMOVED }\end{array}$ & $\begin{array}{c}\text { FINAL } \\
\text { AMOUNT } \\
\text { REGENER- } \\
\text { ATED }\end{array}$ & $\begin{array}{c}\text { FINAL PER } \\
\text { CENTUM } \\
\text { REGENERA- } \\
\text { ATED }\end{array}$ \\
\hline & $m m$. & $m m$ & \\
\hline 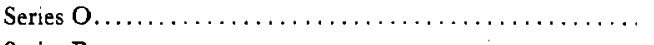 & 3.2 & 1.4 & 44 \\
\hline 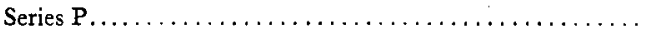 & 5.2 & $2 \cdot 3$ & 44 \\
\hline 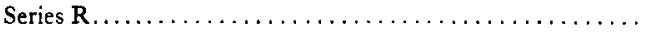 & 10.4 & 5.0 & 48 \\
\hline 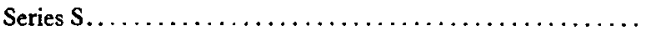 & 14.8 & 7.2 & 48 \\
\hline 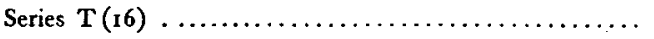 & 20.2 & died & \\
\hline 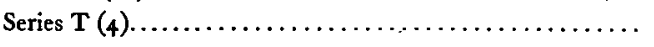 & 20.2 & $4 \cdot 1$ & 20 \\
\hline
\end{tabular}

The two Series $T$ mentioned in the above table, are two divisions of that series; the numbers in parenthesis after each refer to the number of individuals. From this table it is to be seen that the amount of regeneration at the time regeneration ceased, was pro- 


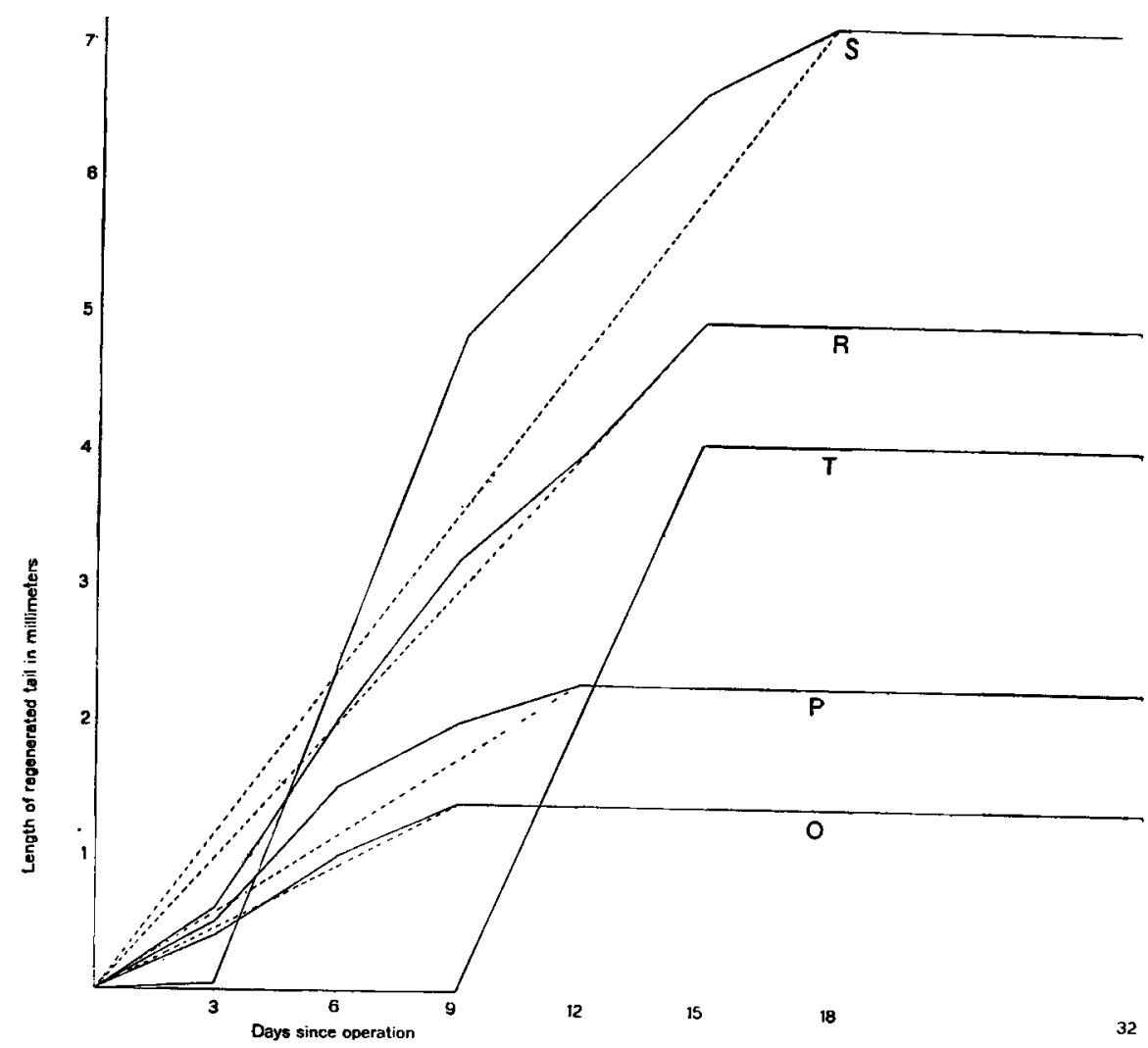

Fig. 1. The curves represent the amount of regeneration for Series $O, P, R, S$, and $T$, Erperiment 4. The abscissa represents time, and the ordinate, the length of the part regenerated in millimeters. The dotted lines are the paths of regeneration, had the amount of regeneration been laid down at a uniform rate, throughout the period of regeneration. They give a standard to which the curve of amount $x$ ay be compared.

Tables 9, I0, II, 12 and 13 give the individual records for the tadpoles of series $O, P, R, S$, Experiment 4.

Table 13 gives the average percentages regenerated for all of the series of Experiment 4 , throughout the period of regeneration. 
portional to the amount removed. The time required by the various series to regenerate these amounts, that is, the length of time during which regeneration took place, was not the same for these several series, but varied in the same direction as the amount removed.

From the experiment as a whole three things are evident: The regeneration of the part removed is not complete; for in every case the regeneration ceased after about 46 per cent of the amount removed had been regenerated. (2) The amount regenerated at the time that regeneration ceased, which was the complete amount laid down during the period of regeneration, varied directly as the amount removed, that is, was proportional to the amount removed. (3) The length of time through which the period of regeneration extended, was not the same for the various amounts of injury; but it grew longer the greater the amount removed.

In this connection, the behavior of the series with $2 \mathrm{~mm}$. removed in Experiment 2, is to be considered. Under that experiment, it was noted that the amount regenerated by the individual with an injury of $2 \mathrm{~mm}$. was the same on the twelfth day as on the fifth day after the operation; in other words, in this case there was no additional regeneration, after the fifth day. The smallest injury inflicted in the present experiment was the removal of $3 \mathrm{~mm}$., that in Series $O$. This series ceased regenerating on the ninth day after the operation. Comparing these two sets of tadpoles, it is seen that, these with $2 \mathrm{~mm}$. removed reached the end of their period of regeneration some four days earlier than those of Series $\mathrm{O}$ with $3 \mathrm{~mm}$. removed. Although this comparison is not strictly accurate, it does show that the time through which regeneration takes place, the duration of the period of regeneration, varies in the same direction as the amount removed.

The control series of Experiment 4 showed no growth during the time of this experiment.

Experiment 5. Temperature, $80^{\circ} \mathrm{F}$. Food, Raw Beef

One hundred tadpoles, body length 37 to $42 \mathrm{~mm}$., were operated upon in the same manner as those of Experiment 4. The experiment was maintained for thirty days in a brooder at $80^{\circ} \mathrm{F}$. The 
results agree exactly with those obtained in Experiment 4. All of the series, except those with $20 \mathrm{~mm}$. removed, ceased regenerating after about 47 per centum of the amount removed had been regenerated. All of the tadpoles of Series $Y(20 \mathrm{~mm}$.) died during the first few days after the operation.

TABLE 6

\begin{tabular}{|c|c|c|c|c|}
\hline & $\begin{array}{l}\text { AMOUNT } \\
\text {-MOVED }\end{array}$ & $\begin{array}{l}\text { AMOUNT } \\
\text { REGENER- } \\
\text { ATED }\end{array}$ & $\begin{array}{l}\text { PER CENTUM } \\
\text { REGENER- } \\
\text { ATED }\end{array}$ & $\begin{array}{l}\text { DAYS OF } \\
\text { REGENER- } \\
\text { ATION }\end{array}$ \\
\hline & $m m$. & $\eta m$. & & \\
\hline Series U. & $3 \cdot 1$ & 1. & 48 & 9 \\
\hline Series $V \ldots \ldots \ldots \ldots \ldots \ldots \ldots \ldots \ldots \ldots$ & $5 \cdot 0$ & 2.4 & 48 & I I \\
\hline Series $W \ldots \ldots \ldots \ldots \ldots \ldots \ldots \ldots \ldots$ & 10.1 & 4.9 & & 15 \\
\hline Series $\mathbf{X} \ldots \ldots \ldots \ldots \ldots \ldots \ldots \ldots \ldots \ldots \ldots \ldots \ldots$ & 14.9 & $7 \cdot 4$ & 49 & 19 \\
\hline Series $\mathbf{Y} \ldots \ldots \ldots \ldots \ldots \ldots \ldots \ldots \ldots$ & 20.1 & died & & \\
\hline
\end{tabular}

Experiment 6. Temperature, $82^{\circ} \mathrm{F}$. No Food Given

Twenty-four small tadpoles, body length 18 to $20 \mathrm{~mm}$., were divided into two series, $\mathrm{AA}$ and $\mathrm{BB}$. The average amount removed in Series AA was $2.5 \mathrm{~mm}$. of tail; in Series BB, $5.2 \mathrm{~mm}$. (See Table I4.)

Series AA ceased to regenerate on the fifth day after the operation, with an amount of $1.4 \mathrm{~mm}$., 55 per cent of the amount removed; Series BB continued to regenerate until the seventh day. Its final amount of regeneration was $2.9 \mathrm{~mm}$., 52 per cent of the amount removed. The only point of difference between these results and those of Experiment 2, since the amount regenerated was proportional to the amount removed, is the absolute per cent of regeneration; this is higher in the present experiment. Two things probably contribute to this difference, the tadpoles are younger and the temperature is higher. Both of these factors increase the rate of regeneration.

As originally planned, it was intended that Experiment 6 should supply some data concerning the surface and the volume of the regenerated parts, but the difficulties encountered in computing these values by the method chosen were so great as to render the 
data too inaccurate to be of value. It will be noticed in Table I4, which gives the individual data of this experiment, that various individuals do not have coinplete records. These were killed to be used in the volume and surface calculations. By the plan adopted, camera lucida drawings were made of the regenerated parts as whole and also of two typical cross-sections of the same. From these the other values were calculated; the results, however, very unsatisfactory.

Experiment 7. Temperature $82^{\circ} \mathrm{F}$. No Food Given

Eighteen tadpoles, body length 27 to $3 \mathrm{I} \mathrm{mm}$., were divided into two series, CC and DD. From Series $\mathrm{CC}$ an average amount of $5.4 \mathrm{~mm}$. was removed; from Series DD, $9.8 \mathrm{~mm}$. This experiment was to ascertain two things: (I) the relation between the amount removed and that regenerated during the first few days after the operation; (2) the average per cent regenerated by tadpoles of this size. (See Tables 15,16 and 17 . Also Fig. 2.)

Fig. 2 shows the same regions in each of its curves as those found in the curves of Experiment 4. There are, as before, four distinct regions. A first, of slow regeneration; a second, of rapid regeneration; a third, of slower regeneration than the second; and the fourth, in which regeneration gradually ceases. Both series regenerated $5^{\circ}$ per cent of the amount removed, making the relation between the amount removed and that regenerated, a proportional one. The final average amounts regenerated by these two series here follow, to wit: Series CC, $2.7 \mathrm{~mm}$., 50 per cent; Series DD, $5.0 \mathrm{~mm}$., $5^{\circ}$ per cent. Series CC ceased to regenerate on the sixth day after the operation; Series DD, on the tenth. The regeneration in these two series ceased when the amount removed was proportional to the amount regenerated; and the time consumed in regenerating this amount varied with the level of injury. The point of largest interest in this connection is the first part of the curves of the two series. Neither curve showed great regeneration during the first two or three days after the operation; the rapid regeneration coming several days after the operation in both cases. This experiment was maintained twelve days. 


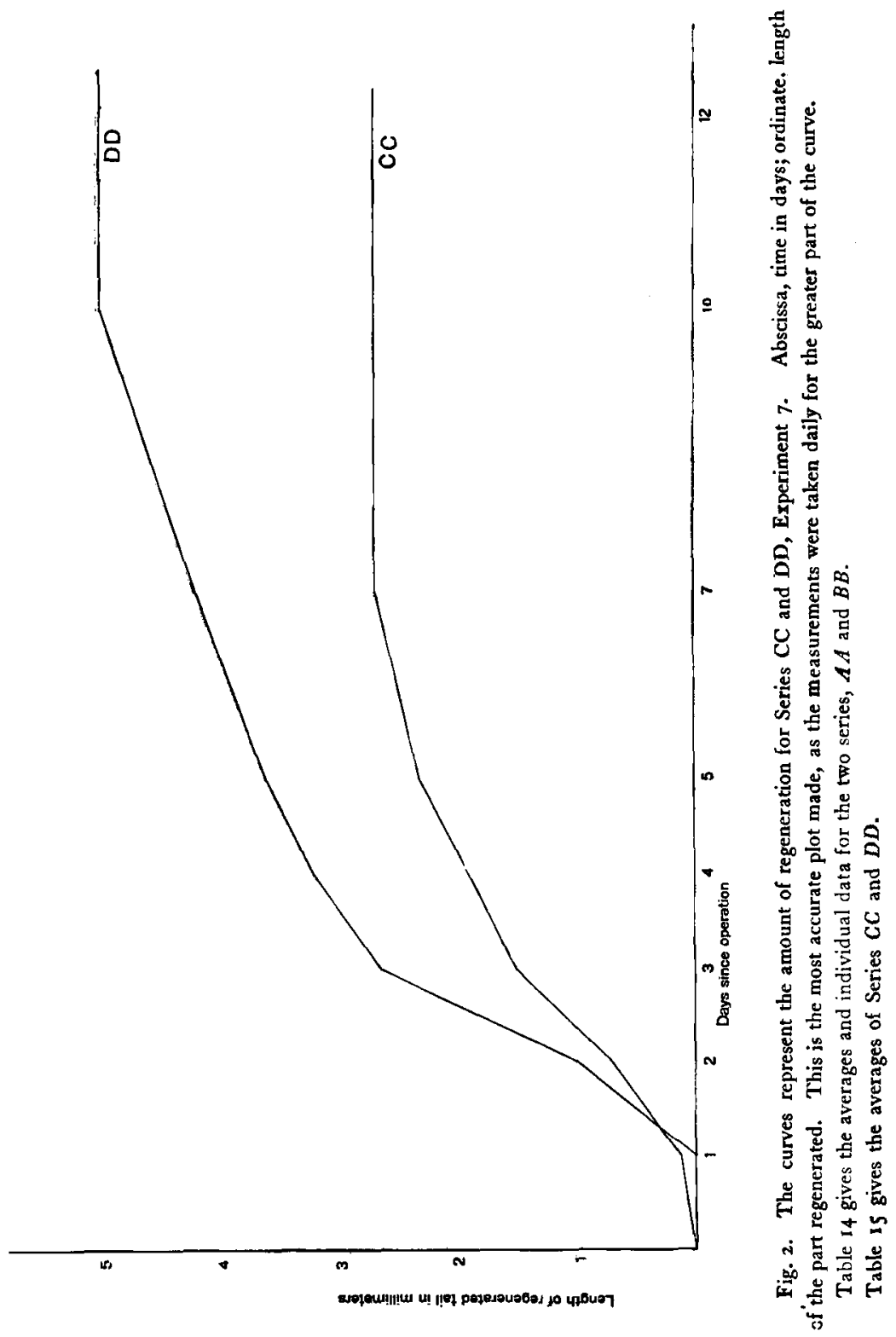


Experiment 8. Temperature, $82^{\circ} \mathrm{F}$. No Food Given

This experiment was made with twenty tadpoles, average body length $45 \mathrm{~mm}$. One-half of these, Series EE, was injured by the removal of an average amount of $5.1 \mathrm{~mm}$. of tail; the other half, Series FF, $10.2 \mathrm{~mm}$. The object of this experiment was to obtain additional data concerning the relation of the amount regenerated during the first few days after the infliction of the injury, to the amount removed. These tadpoles (see Fig. 3, and Table 18) also ceased regenerating before the entire amount removed had been restored. Series EE ceased to regenerate after having regenerated $2.3 \mathrm{~mm}$., 47 per cent of the amount removed, on the ninth day. Series FF regenerated until the nineteenth day, when its average amount was $4.4 \mathrm{~mm}$., 44 per cent of the amount removed. This experiment lasted twenty-two days.

\section{Experiment 9. Temperature $70^{\circ} \mathrm{F}$. Food, Raw Beef and Spirogyra}

Two series, Series GG and HH, of twenty tadpoles each, body length 37 to $42 \mathrm{~mm}$. constituted this experiment. Its object was to ascertain the constancy of the regenerated part after regeneration ceased. From Series GG $5 \mathrm{~mm}$. of tail were removed; from Series $\mathrm{HH}$, ro $\mathrm{mm}$. Both series were kept on top of a table in a room whose average temperature was about $70^{\circ} \mathrm{F}$., for forty-two days. Series GG ceased regenerating on the eleventh day with 40 per cent of the part removed, restored. Series $\mathrm{HH}$ did not regenerate after the nineteenth day, its final per cent regenerated being 39 . These per cents remained the same until the experiment was discontinued.

\section{Experiment Io. Temperature, $74^{\circ} \mathrm{F} . \quad$ No Food Given}

The eggs, from which the animals used in this experiment hatched, were brought into the laboratory on April 10, 1908. The tadpoles hatched out six days later. When they were a week old, thirty-two, of an average body length of $12.2 \mathrm{~mm}$., were chosen. Four series were used, a control of uninjured tadpoles and three 

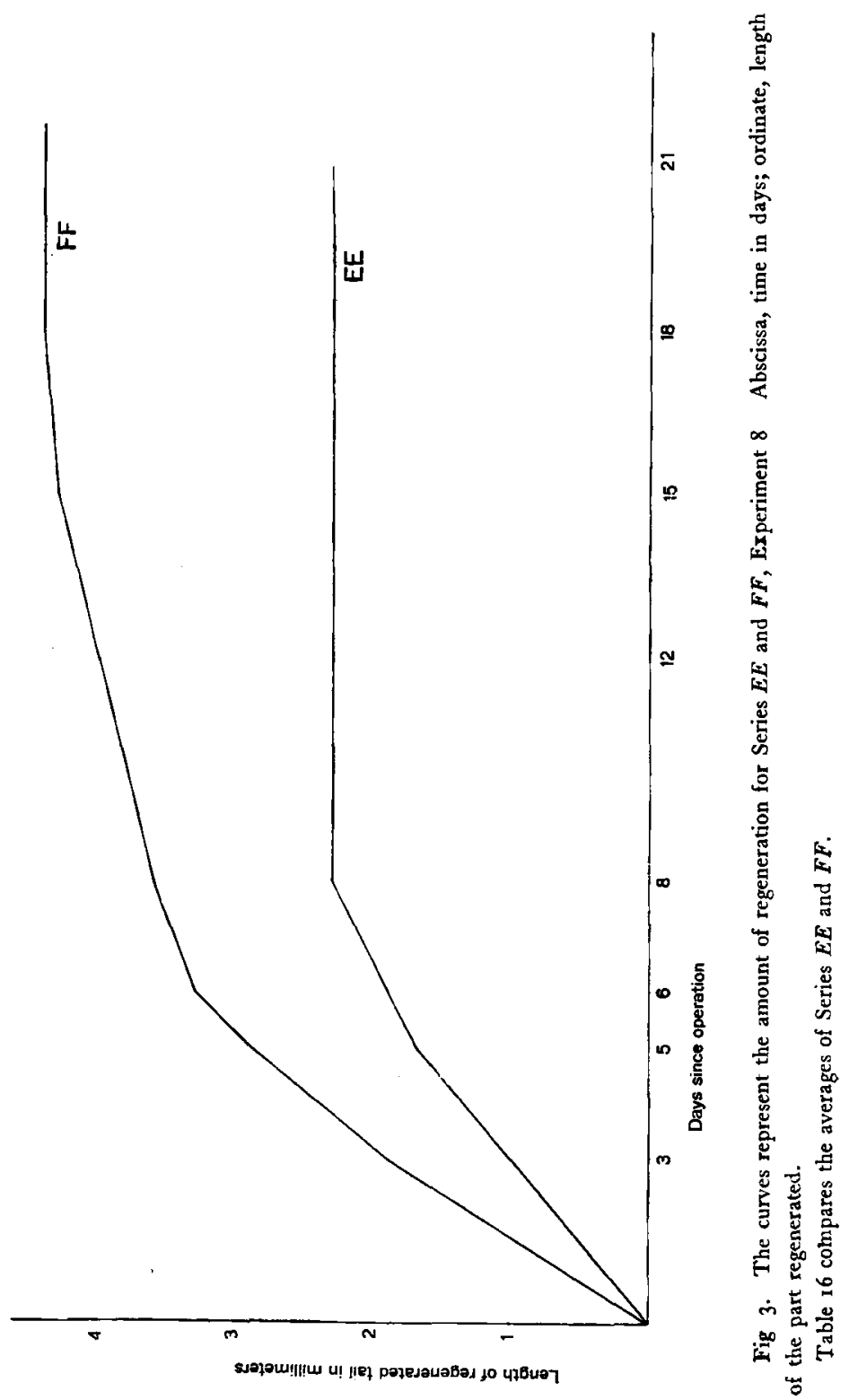
other series operated upon as follows: one-fourth of the tail was removed from eight; one-half of the tail from another eight; and three-fourths of the tail from a third eight. This experiment was unexpectedly brought to a close'on the fourth day after the operation, and is mentioned here for but two things. (I) During the four days of the experiment some of the individuals of the series which had lost one-fourth of the tail, regenerated more than Ioo per cent of the part removed. This is the only case in these experiments, in which all of the removed part was regenerated. It must be noted, however, that during these four days the control series grew from $12.2 \mathrm{~mm}$. to $16 \mathrm{~mm}$., body length. Almost all of the animals with three-fourths of the tail removed, died.

\section{DISCUSSIONS AND CONCLUSIONS}

\section{Temperature}

Temperature was found to influence the amount of regeneration Its effect is direct, and the amount of regeneration varies in the same direction as the temperature, between two thermal limits. In Experiments 2 and 3, tadpoles regenerated the tail at $66^{\circ} \mathrm{F}$. but did not regenerate at $57^{\circ} \mathrm{F}$. even though the other conditions of the experiments were the same. As the temperature factor was the only variable in these two experiments, the lack of regeneration at $57^{\circ} \mathrm{F}$. must be ascribed to the effect of temperature upon the processes producing regeneration. This lack of regeneration at $57^{\circ} \mathrm{F}$. is of particular interest since the animals did not die, although they did not regenerate. The minimum temperature at which regeneration takes place, although not absolutely determined, is between $66^{\circ}$ and $57^{\circ} \mathrm{F}$. for the type of tadpoles used. Considering the other temperatures in Experiments 2 and 3 , it is seen that tadpoles regenerated readily at $76^{\circ} \mathrm{F}$. while they died in less than twenty-four hours at $96^{\circ} \mathrm{F}$. The temperature at which most of the experiments in this work were maintained, was $78^{\circ} \mathrm{F}$. Tadpoles regenerated readily at that temperature. The highest temperature used, at which regeneration took place, was $82^{\circ} \mathrm{F}$. in Experiment 6 . On the contrary, tadpoles were kept at $47^{\circ} \mathrm{F}$., I $9^{\circ}$ below the lowest temperature at which they regenerated, 
and they still remained as active as those kept at the higher temperatures, at which regeneration took place. It is also known, that tadpoles will live at even a lower temperature than $47^{\circ} \mathrm{F}$; ; they have been collected by the writer from ponds in which there was floating ice, and the water of which was certainly not above $38^{\circ} \mathrm{F}$. Taking the temperatures as observed, however $\left(57\right.$ to $96^{\circ} \mathrm{F}$.), regeneration is absent, present and prohibited by death, in a gamut of forty degrees. The absolute thermal limits of regeneration, as found in these experiments, were $82^{\circ}$ and $66^{\circ} \mathrm{F}$., a range of but $16^{\circ}$. Between these limits the data collected show the amount regenerated to vary in the same direction with the temperature. This is particularly apparent in Experiments 2 and 3, but may be shown to be the rule for all of the experiments by cross-comparison.

Two conclusions were drawn from the data collected concerning the relation of temperature to the amount regenerated:

I There is a minimum temperature, below which tadpoles live. but do not regenerate the tail. It lies between $57^{\circ}$ and $66^{\circ} \mathrm{F}$. for tadpoles, body length $37-42 \mathrm{~mm}$.

2 Between $66^{\circ}$ and $84^{\circ} \mathrm{F}$., the amount of regeneration varies in the same direction as the temperature.

\section{Level of Injury}

Spallanzani in 1769 made the following interesting statement concerning the relation of the level of injury to the amount regenerated, in the tadpole tail. He says: "If the whole tail, or very near the whole tail, be cut off, the tadpoles go to the bottom of the water and there lie down and perish. But if a lesser part be taken off, not one of them dies; and all without exception, recover what they lost. . . . . Nature observes the following laws in the growth of these reproductions. They are more considerable, when a great part is taken off; not so large after a lesser section. and least of all when a very small bit has been cut off. The greatest length seems however, rather to take place, when the tail is divided in the middle, than when the section is higher."

The relations of the level of injury to the regeneration were found to be precisely those pointed out in the observations of Spallanzani. First as regards the level from which the removal of the tail pro- 
duced a fatal injury. In Experiment 4 it was noted that Series $\mathrm{T}(20 \mathrm{~mm}$.) had a mortality of 80 per cent; and that the four tadpoles which did survive the loss of $20 \mathrm{~mm}$. of tail, regenerated abnormally. All of the tadpoles in the series with $20 \mathrm{~mm}$. removed, died, in Experiment 5. Since tadpoles of the same size and subjected to the same conditions as these animals just mentioned, regenerated rapidly from the $15 \mathrm{~mm}$. level, the $20 \mathrm{~mm}$. level, in the light of the above statements, was considered the lowest level (that is the level nearest the tip of the tail) from which the removal of the tail produced fatal injury. Injury at the 20 $\mathrm{mm}$. level, removed about 80 per cent of the tail, the average tail length of these tadpoles being $26 \mathrm{~mm}$. The entire tail was removed from several tadpoles, independent of the experiments mentioned, and all of the animals so operated upon died within two or three days after the injury.

Consider now the levels at which regeneration took place. Beginning near the tip of the tail, injuries at all levels were followed by regeneration until the fatal level, $20 \mathrm{~mm}$., was reached. The per cent of the part removed, regenerated from the various levels, was the same regardless of the level; that is, the amount regenerated was proportional to the amount removed. The time, however, consumed in regenerating grew longer, as has already been mentioned, as the level of injury approached the head. Although the length of the period of regeneration was greater for the regeneration from the higher (the more cephalad) levels; this period was relatively longer for the series injured at the lower (the more caudad) levels, making the rate of regeneration higher, the more cephalad the injury. Take for example the final amounts of Experiment 4 which are typical. Together with the time required by each for this regeneration, and the average rate per day, in millimeters, they may be grouped in the following table: 
TABIE 7

\begin{tabular}{|c|c|c|c|c|}
\hline & $\begin{array}{l}\text { AMOUNT } \\
\text { REMOVED }\end{array}$ & $\begin{array}{c}\text { FINAL } \\
\text { AMOUNT } \\
\text { REGENER- } \\
\text { ATED }\end{array}$ & $\begin{array}{c}\text { DAYS OF } \\
\text { REGENERA- } \\
\text { TION }\end{array}$ & $\begin{array}{l}\text { AVERAGE } \\
\text { DAILY RATr } \\
\text { OF REGEN- } \\
\text { ERATION }\end{array}$ \\
\hline & $m m$. & $m m$. & & $m m$ \\
\hline Series $0 \ldots \ldots \ldots \ldots \ldots \ldots \ldots \ldots \ldots \ldots \ldots$ & $3-2$ & 1.4 & 9 & 0.16 \\
\hline 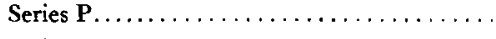 & 5.2 & $2 \cdot 3$ & 12 & 0.19 \\
\hline 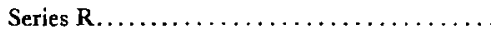 & 10.4 & 5.0 & 15 & 0.33 \\
\hline Series $\mathbf{S} \ldots \ldots \ldots \ldots \ldots \ldots \ldots \ldots \ldots \ldots$ & 14.8 & 7.2 & 18 & 0.40 \\
\hline Series $T(16) \ldots \ldots \ldots \ldots \ldots \ldots \ldots \ldots \ldots$ & 20.2 & $\circ$ & Died in 4 & to 6 days \\
\hline Series $\mathbf{T}(4) \ldots \ldots \ldots \ldots \ldots \ldots \ldots \ldots$ & 20.2 & 4.1 & 15 & 0.27 \\
\hline
\end{tabular}

From this table it is to be seen that although the per cent regenerated was the same, regardless of the amount removed, the rate of regeneration varied with the level of injury, as the level moved away from the tip of the tail. Precisely the same relation between the level of injury and the rate of regeneration has been found to obtain for the arms of the star-fish, Asterias, by King, 1898. She states: "The rate of regeneration is greatest from the disc and decreases directly towards the tip of the arm." Morgan, in I902, stated that the regeneration from straight cuts across the tail of the fish, Fundulus, proceeded more rapidly from the higher levels. In the recent paper of Stockard on the regeneration of Cassiopea xamachana, one finds the following observation: "The regeneration rate is fastest at the deepest level, and slower as the level nears the margin.

The Medusa regenerates tissue faster the farther away from the periphery the cut is made, as though the more tissue removed the less uninjured body-surface remained to exert a retarding influence."

Thus the data collected concerning this relation of the amount and rate of regeneration from various levels of the same organ, agree in supporting the hypothesis that regeneration always proceeds more rapidly from the higher or deeper levels of the same part or organ.

The amount regenerated by the four individuals surviving the removal of $20 \mathrm{~mm}$. of tail in Series $T$ was added to Table 7 , as 
it showed the effect of extremely severe injury upon the rate of regeneration. The rate of regeneration of these four was lower than that of the Series R (10 $\mathrm{mm}$.); this fact is probably to be accounted for by the effect or shock of the extreme injury. No conclusion, however, can be reached from these four animals alone.

Another interesting relation between the level of injury, and regeneration, is noticed in the length of the first period of regeneration, the one of low rate, in all of the experiments. This period is longer the higher the level of injury, that is, the greater the amount removed. It does not, however, increase proportionally with the level of injury. This difference in the length of this first period of regeneration may be due to one or both of two things: (I) The direct effect of the injury itself, that is, the shock of injury occasioned by the sudden loss of a quantity of blood and the overstimulation of the nervous system; that is, the sudden appearance of the abnormal factor, injury, in normal life; or (2) the delay due to the healing over of the surface of the wound. Either of these would prolong this first period of slow regeneration; the former, since the amount of injury, that is, the absolute amount of tissue removed, varies with the level of injury; the latter, since the area of the cross-section of the tail, hence the area to be healed over, varies with the level of injury. Data were not collected from which conclusions could be drawn concerning this point, but the histological investigations of Durbin on the early stages of regeneration of the tadpole, show the latter to be the more probable.

The following conclusions are taken from the data collected:

I The level of injury first producing death was $20 \mathrm{~mm}$. cephalad from the tip of the tail, tail length $26 \mathrm{~mm}$.

2 The rate of regeneration varies as the level of injury until the $20 \mathrm{~mm}$. level is reached.

3 The first slow period of regeneration increases in length the higher the level of injury.

Relation of the Amount Regenerated to the Amount Removed

In both the experiment which suggested these investigations, and Experiment I, it was noted that the amount regenerated at the end of twelve days after the operation, varied directly, that is, 
was proportional to the amount removed. In Experiments 2 and 3 , the same relation existed between the amount regenerated and that removed, at the end of the twelfth day as was noted in the two previous experiments; this relation, however, did not obtain at the end of the fifth day after the operation. Subsequent experiments gave two important facts in this connection. (I) Regeneration ceases before the part removed has been completely regenerated; and (2) the amount regenerated is proportional to the amount removed, regardless of the absolute amount removed, only at the time regeneration ceases. The tadpoles from which these data were collected did not grow while under observation, as shown by the control series. In but a single case did the tadpoles used regenerate the complete amount removed; these animals were but a week old and growing rapidly (Experiment 10). There is a very probable explanation for this incomplete regeneration on the basis of the state of development of the tadpole. Kammerer found that the rate of regeneration of tadpole tails varied not with the absolute age of the tadpole, but with its state of development. Suppose then, that there is a time (as there probably is) while the tadpole is very young, that it is capable of regenerating completely a part of the tail lost by injury. Data collected from observations on various animals show younger animals, as a rule, to regenerate more readily than older ones; that is, animals at a more advanced stage of development regenerate less rapidly. This fact was pointed out as early as $\mathrm{I} 786$, by Broussonet in his observations on the regeneration of the tails of fishes. It is also known, that the adult frog, normally, does not regenerate. The tadpole, then, must lose its ability to regenerate in one of two ways: either suddenly, at some particular point in its life; or gradually throughout its larval life. The latter is the more probable, and is substantiated by the data collected. If the ability to regenerate be dependent upon the state of development it were possible then to establish a "regenerative coefficient" for the various ages of tadpoles; which coefficient would be the maximum per cent that the particular stage is capable of regenerating, under the best conditions for regeneration. This per cent, naturally, however, would not be regenerated; for various other factors also control the 
per cent regenerated. In Experiments 2 and 3, for example, the various per centums, from zero to fifty, were regenerated by the several series, although the tadpoles comprising these were of the same age. This difference was due to the effect of temperature; and similarly other factors may be shown to influence the amount regenerated. A confirmation of the hypothesis, that the age or state of development does influence the amount regenerated and that the more nearly the adult condition is reached the lower the rate of regeneration, occurs in the following Table, constructed from the percentages regenerated in Experiments 6, 7, and 8, which were subjected to the same conditions.

TABLE 8
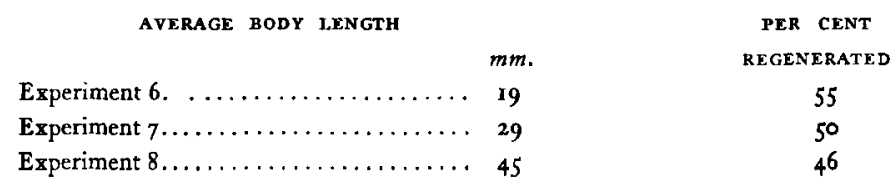

These comparisons are, perhaps, not absolutely accurate, since, as explained in the first part of this paper, body length had to be taken as an index of the age or state of development; but allowing for this inaccuracy, there are definite differences between the amounts regenerated by the tadpoles of various sizes under the same conditions.

At this point, the process of regeneration itself should be considered. Regenerated tissue is the direct product of cell division, and accordingly, the rate of regeneration is dependent largely upon the rate of cell division. According to Morgan's tension theory, the cell tends to divide until the external (that is, extracellular) pressure and tension are equal to the force within itself, causing it to divide. When these forces are equal, differentiation begins. Minot and others have shown that the more embryonic the cell, the more it tends to divide; in other words, the greater this force which prompts the cell to divide despite extra-cellular forces. The tail of a tadpole is an embryonic organ; hence, probably contains large numbers of embryonic cells. As previously mentioned, Kammerer found the rate of regeneration to vary with 
the state of development of the tadpole. Taking the term "state of development" used by Kammerer, to mean the relative embryonic age of the tadpole, the larger the tadpole, that is, the greater its bodylength, the less embryonic the condition of the tail. Applying this to regeneration, take for example, the tail of a tadpole that has had approximately ten millimeters removed from it. By the very presence of injury, which has removed part of the tail, the cells on the exposed surface are given a chance to divide; as the pressure and tension at that point have been reduced. If the conditions of temperature, food, etc., are optimum, and the injury itself has not overwhelmed the animal (that is, such injuries as are fatal) these cells exposed will divide because of a lack of equilibrium of forces. They will also continue to divide until the extra-cellular forces are equal to the force producing cell-division. When this point has beeh reached, they will cease dividing, and differentiate. The data collected by Durbin on this point show two distinct regions in the period of regeneration as are to be expected from the above statements. (I) A region of rapid celldivision and no differentiation, which extends over the first part of the regeneration period; (2) a region of differentiation with little cell-division immediately following the first. The question comes at once, as to the per centum regenerated before cell-division ceases. This is dependent upon the state of development of the animal; for the amount of force producing cell-division varies with the relative embryonic age of the cells. This theory of regeneration is confirmed by the second fact mentioned at the first of this discussion, namely, that the final amount regenerated in series under the same conditions, by tadpoles of the same size, was always the same per cent of the amount removed, regardless of the level of injury. Consider, for example, two series of tadpoles of the same size and under the same conditions, one with Io $\mathrm{mm}$. removed, and the other with $5 \mathrm{~mm}$. removed. The cells exposed have the same division potential, consequently, the same ability to overcome the extra-cellular forces inhibiting cell-division; and because of this fact, they will continue to divide until the same force is exerted against them. It is evident that the regeneration of two and one-half millimeters by both series would not produce 
the same conditions of pressure and tension in the two sets of tails. The series with Io $\mathrm{mm}$. would probably have to regenerate $5 \mathrm{~mm}$. to bring about a condition similar to that in the tail, that had regenerated two and one-half millimeters, but had lost only $5 \mathrm{~mm}$. through injury. This is precisely the method of regeneration followed by all of the series observed. Each regenerated an amount proportional to that removed. This is to be expected in view of the last statement, for the regeneration would cease when the cells dividing had reached a point at which the extra-cellular force was equal to that force causing them to divide; and since these cells had equal regenerative potential to start with, the conditions of pressure and tension would only be equalized when the amount regenerated was proportional to the amount removed.

Another point in favor of this view of the cause of the proportional regeneration from various levels, is the sequence of the regions comprising the curves of regeneration. The first region, that of low rate of regeneration, is due to the immediate shock of injury and the healing over of the exposed surface; the second, of rapid regeneration, is the period during which the minimum resisttance is offered to cell-division; the third, that in which the rate of regeneration suddenly decreases, is produced by the rapid celldivision of the second region, which has brought up the tension of the tail to a point almost equal to that, at which the extra-cellular forces are equal to those causing cell-division; the fourth and last region, that in which regeneration gradually ceases, is that in which the extra-cellular forces finally overcome cell-division.

\section{GENERAL SUMMARY}

I The tadpoles observed did not completely regenerate the part of tail removed.

2 The absolute amount regenerated was proportional to the amount removed, whether this was large or small; the per cent regenerated, by series under uniform conditions, was the same, if they were of the same relative age, regardless of the absolute amount removed.

3 The per cent regenerated, other conditions being the same; varied with the relative age of the tadpole. 
4 The rate of regeneration increased directly with the level of the injury, as the level of injury moved cephalad from the tip of the tail. The removal of $20 \mathrm{~mm}$. of tail constituted a fatal injury to tadpoles whose tail length was $26 \mathrm{~mm}$.

5 Other factors being the same, the amount regenerated varied in the same direction as the temperature, between $66^{\circ}$ and $84^{\circ} \mathrm{F}$.

6 There is a temperature limit below which tadpoles will live but do not regenerate the tail. This limit was between $57^{6}$ and $66^{\circ} \mathrm{F}$.

7 There are four distinct periods of regeneration: (I) the first of slow regeneration during the first few days after the operation; (2) the second of rapid regeneration; (3) a third in which the regeneration is much slower than the second; (4) a last period in which the processes of regeneration gradually cease.

8 The time elapsing between the operation and the cessation of regeneration, that is, the period of regeneration, varies with the level of injury. The higher the injury the longer this period; though the period is relatively longer for the series operated upon at the lower levels.

\section{BIBLIOGRAPHY}

Broussonet, I786-Observations sur la régénération de quelques parties du corps des Poissons. Hist. de l'Acad. Roy. des Sciences.

Durbin, Marion 'o9-An Analysis of the Rate of Regeneration throughour the Regeneration Process. Jour. Exp. Zoöl, vol. vii.

Elurs, Max M. '08-Some Notes on the Factors Controlling the Rate of Regeneration in Tadpoles of Rana clamitans. Biological Bulletin, vol. xiv.

KAMmerer, PAUL '05-Ueber die Abhängigkeit des Regenerationsvermögens der Amphibienlarven von Alter, Entwicklungsstadium und spezifischer Grösse. Roux's Archiv f. Entw. Mech., Bd. 19.

King, Helen D. ' $98-$ Regeneration in Asterias vulgaris. Roux's Archiv f. Entw. Mech., Bd. 7 .

Morgan, T. H. 'O2-Further Experiments on the Regeneration of the Tail of Fishes. Roux's Archiv f. Entw. Mech., Bd. xiv.

'o6-Physiology of Regeneration. Jour. Exp. Zoöl., vol. iii.

Spallanzani (Lazaro) Abbé i 769-Prodromo. An Essay on Animal Reproductions. Translated from the Italian by M. Maty, London.

Stockard, Charles R. 'o8-An Experimental Study of the Rate of Regeneration in Cassiopea xamachana. Cannegie Institution Publications. 
Amount of Tail Regenerated to Removed in Tadpoles 449

TABLE 9-Series 0

\begin{tabular}{|c|c|c|c|c|c|c|c|}
\hline CAT. No. & $\begin{array}{c}\text { BODY } \\
\text { LENGTH }\end{array}$ & $\begin{array}{c}\text { TAIL } \\
\text { LENGTH }\end{array}$ & $\begin{array}{l}\text { AMOUNT } \\
\text { REMOVED }\end{array}$ & $\begin{array}{c}3 \text { DAY } \\
\text { AMOUNT } \\
\text { REG. }\end{array}$ & $\begin{array}{c}6 \text { DAY } \\
\text { AMOUNT } \\
\text { REG. }\end{array}$ & $\begin{array}{c}9 \text { DAY } \\
\text { AMOUNT } \\
\text { REG. }\end{array}$ & $\begin{array}{c}\text { 32 DAY } \\
\text { ANOUNT } \\
\text { REG. }\end{array}$ \\
\hline 704 & 41.2 & 25.9 & 3.1 & 0.4 & 1.2 & $1 \cdot 3$ & 1.3 \\
\hline 708 & 40.3 & 25.6 & 3.0 & 0.4 & 1.0 & 1.2 & I.I \\
\hline 715 & 39.0 & 25.0 & $3 \cdot 5$ & 0.4 & 0.9 & 1.1 & 1.2 \\
\hline 716 & 37.8 & $24 \cdot 3$ & 3.0 & 0.4 & I. 0 & $1 \cdot 3$ & 1.2 \\
\hline 720 & 41.0 & 26.0 & $3 \cdot 1$ & 0.4 & 1.0 & 1.2 & 1.2 \\
\hline 723 & 42.0 & $27 \cdot 3$ & 3.0 & 0.4 & I , I & 1.4 & 1.4 \\
\hline 729 & 40.0 & 26.0 & 3.0 & 0.4 & I. I & 1.2 & $1 \cdot 3$ \\
\hline 735 & $37 \cdot 5$ & $24 \cdot 5$ & 3.0 & 0.4 & 1.0 & 1.2 & $1 \cdot 3$ \\
\hline 741 & 41.0 & 25.6 & 3.0 & 0.5 & I . I I & I. 2 & I. 2 \\
\hline 743 & 41.6 & 27.2 & $3 \cdot 5$ & 0.3 & 1.0 & 1.4 & $1 \cdot 3$ \\
\hline $75^{1}$ & 40.0 & 26.0 & $3 \cdot 5$ & 0.4 & I.I & 1.5 & 1.4 \\
\hline $75^{6}$ & 37.2 & $29 \cdot 3$ & 3.5 & 0.3 & 1.0 & 1.6 & 1.4 \\
\hline 760 & $43 \cdot 3$ & 28.5 & 3.0 & 0.3 & I. I & I.I & 1.2 \\
\hline 769 & 37.0 & 24.6 & $3 \cdot 4$ & 0.5 & I.I & 1.2 & 1.2 \\
\hline 777 & $3^{8} \cdot 5$ & 25.0 & 3.5 & 0.5 & I . I & 2.2 & 2.2 \\
\hline 779 & 40.8 & 26.5 & $3 \cdot 5$ & 0.4 & I. 0 & $\mathrm{I} \cdot 3$ & $1 \cdot 3$ \\
\hline $7^{81}$ & $37 \cdot 9$ & $24 \cdot 7$ & 3.6 & 0.5 & 0.9 & I. 7 & I. 7 \\
\hline 787 & $37 \cdot 4$ & 26.0 & $3 \cdot 5$ & 0.4 & 1.2 & 1.6 & 1.6 \\
\hline 789 & $37 \cdot 5$ & 23.9 & 3.0 & 0.4 & 0.9 & 1.2 & 1.2 \\
\hline 791 & 40.5 & 26.0 & 3.0 & 0.4 & 0.9 & $\mathbf{I}, \mathbf{I}$ & 1.2 \\
\hline \multicolumn{3}{|c|}{ Averages $\ldots \ldots \ldots \ldots \ldots \ldots \ldots$} & 3.2 & 0.4 & 1.0 & 1.4 & 1.4 \\
\hline
\end{tabular}


TABLE 10-Series $P$

\begin{tabular}{|c|c|c|c|c|c|c|c|c|}
\hline $\begin{array}{l}\text { CAT. } \\
\text { No. }\end{array}$ & $\begin{array}{c}\text { BODY } \\
\text { LENGTH }\end{array}$ & $\begin{array}{c}\text { TAIL } \\
\text { LENGTH }\end{array}$ & $\begin{array}{l}\text { AMOUNT } \\
\text { REMOVED }\end{array}$ & $\begin{array}{c}3 \text { DAY } \\
\text { AMOUNT } \\
\text { REG. }\end{array}$ & $\begin{array}{c}6 \text { DAY } \\
\text { AMOUNT } \\
\text { REG. }\end{array}$ & $\begin{array}{c}9 \text { DAY } \\
\text { AMOUNT } \\
\text { REG. }\end{array}$ & $\begin{array}{l}\text { I2 DAY } \\
\text { AMOUNI } \\
\text { REG. }\end{array}$ & $\begin{array}{c}3^{2} \text { DAY } \\
\text { AMOUNT } \\
\text { REG. }\end{array}$ \\
\hline 706 & 37.8 & 24.0 & 5.0 & 0.5 & 1.4 & 2.0 & 2.0 & 2.1 \\
\hline 711 & 40.7 & 26.5 & 5.0 & 0.5 & 1.5 & 1.8 & 2.0 & 2.1 \\
\hline 713 & 43.1 & 27.5 & 5.0 & 0.4 & 1.4 & 1.7 & 1.9 & 2.0 \\
\hline 719 & $4^{2} \cdot 3$ & 27.0 & 5.2 & 0.6 & 1.4 & 1.8 & 2.3 & 2.3 \\
\hline 725 & 40.6 & 26.1 & 5.0 & 0.6 & $1 \cdot 3$ & 1.8 & 1.8 & 2.0 \\
\hline 726 & 41.0 & 26.5 & $5 \cdot 1$ & 0.5 & 1.5 & 2.0 & 2.2 & 2.2 \\
\hline $73^{6}$ & 43.5 & 28.0 & 6.0 & 0.5 & 1.6 & 2.1 & 2.3 & 2.3 \\
\hline $74^{8}$ & 41.6 & 26.3 & 5.0 & 0.4 & 1.5 & 1.9 & 2.1 & 2.1 \\
\hline 752 & $3^{8.4}$ & 25.2 & 5.0 & 0.5 & 1.6 & 2.0 & 2.2 & 2.2 \\
\hline 755 & 37.6 & 25.0 & $5 \cdot 5$ & 0.5 & 1.4 & 2.0 & $2 \cdot 3$ & $2 \cdot 3$ \\
\hline 765 & 39.9 & 26.2 & $5 \cdot 1$ & 0.4 & 1.5 & 2.0 & 2.3 & 2.0 \\
\hline 766 & 40.0 & 26.0 & 6.0 & 0.6 & 1.4 & I. 8 & 2.0 & 2.0 \\
\hline 773 & 40.5 & 27.0 & $5 \cdot 5$ & 0.5 & 1.5 & 2.0 & 2.3 & $2 \cdot 3$ \\
\hline 783 & 39.0 & $25 \cdot 5$ & 5.0 & 0.5 & 1.4 & 1.9 & 2.I & 2.I \\
\hline $78_{4}$ & 41.8 & 28.0 & 5.7 & 0.6 & 1.6 & 2.0 & $2 \cdot 3$ & 2.2 \\
\hline 792 & $3^{8.0}$ & 24.8 & 5.0 & 0.5 & I. 6 & 2.5 & 2.5 & 2.2 \\
\hline 795 & 39.4 & 25.0 & $5 \cdot 4$ & 0.4 & 1.5 & 2.5 & 2.5 & $2 \cdot 3$ \\
\hline 798 & 37.0 & 24.0 & 5.0 & 0.5 & 1.6 & 2.2 & 2.5 & 2.4 \\
\hline 805 & 42.5 & 27.8 & $5 \cdot 4$ & 0.5 & 1.5 & 2.0 & $2 . I$ & 2.1 \\
\hline 806 & 39.5 & 26.2 & 4.9 & 0.4 & I. 5 & I.8 & 2.2 & 2.2 \\
\hline \multicolumn{4}{|c|}{ 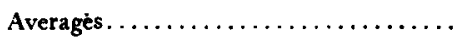 } & 0.5 & 1.5 & 2.0 & $2 \cdot 3$ & 2.3 \\
\hline
\end{tabular}


Amount of $T$ ail Regenerated to Removed in Tadpoles $45 \mathrm{I}$

TABLE I I-Series $R$

\begin{tabular}{|c|c|c|c|c|c|c|c|c|c|}
\hline $\begin{array}{l}\text { CAT. } \\
\text { No. }\end{array}$ & $\begin{array}{c}\text { BODY } \\
\text { LENGTH }\end{array}$ & $\begin{array}{c}\text { TAIL } \\
\text { LENGTH }\end{array}$ & $\begin{array}{l}\text { AMOUNT } \\
\text { REMOVED }\end{array}$ & $\begin{array}{c}3 \text { DAY } \\
\text { AMOUNT } \\
\text { REG. }\end{array}$ & $\begin{array}{c}6 \text { DAY } \\
\text { AMOUNT } \\
\text { REG. }\end{array}$ & $\begin{array}{c}9 \text { DAY } \\
\text { AMOUNT } \\
\text { REG. }\end{array}$ & $\begin{array}{c}\text { I } 2 \text { DAY } \\
\text { AMOUNT } \\
\text { REG. }\end{array}$ & $\begin{array}{c}15 \text { DAY } \\
\text { AMOUNT } \\
\text { REG. }\end{array}$ & $\begin{array}{c}3^{2} \text { DAY } \\
\text { AMOUNT } \\
\text { REG. }\end{array}$ \\
\hline 703 & 39.4 & 25.5 & 9.6 & 0.6 & 2.0 & 2.8 & 3.8 & $4 \cdot 5$ & $4 \cdot 5$ \\
\hline 701 & 41.0 & 26.8 & 9.8 & 0.6 & 2.2 & 2.9 & 3.8 & 4.9 & 4.9 \\
\hline 721 & 40.0 & 25.4 & 10.0 & 0.6 & 2.0 & $3 \cdot 3$ & 4.2 & 4.4 & 4.8 \\
\hline 731 & $37 \cdot 5$ & 24.0 & 10.0 & 0.6 & 2.0 & 3.0 & 4.0 & $5 \cdot 1$ & 5.1 \\
\hline 722 & 39.4 & 25.2 & 10.0 & 0.6 & 2.0 & 3.1 & 4.1 & 5.0 & 5.0 \\
\hline $73^{2}$ & $37 \cdot 3$ & 23.4 & 10.0 & 0.6 & 2.0 & 3.0 & 3.9 & 4.9 & 4.9 \\
\hline 745 & $3^{8.8}$ & $25 \cdot 3$ & 9.6 & 0.6 & 1.9 & 2.8 & 4.1 & 4.4 & 4.6 \\
\hline $75^{8}$ & 41.0 & 27.5 & 9.8 & 0.7 & 1.9 & 2.8 & 4.0 & 4.0 & 4.1 \\
\hline 762 & 39.0 & 26.0 & 10.5 & 0.7 & 2.1 & 3.8 & $4 \cdot 3$ & 5.0 & 5.0 \\
\hline 767 & 40.4 & 26.0 & 10.0 & 0.7 & 2.3 & 3.4 & 4.0 & 4.9 & 4.9 \\
\hline 768 & 40.5 & 26.2 & 10.0 & 0.7 & 2.3 & 3.8 & 4.1 & $5 \cdot 4$ & $5 \cdot 4$ \\
\hline $77^{8}$ & $4^{1} \cdot 4$ & 26.6 & 11.0 & 0.6 & $2 \cdot 3$ & 3.6 & 4.9 & 5.5 & 5.5 \\
\hline $7^{80}$ & 39.2 & 25.0 & 9.6 & 0.7 & 1.9 & 2.9 & 4.0 & 5.0 & 5.0 \\
\hline 786 & 40.4 & 25.7 & 10.5 & 0.6 & 2.1 & 3.2 & 4.1 & $4 \cdot 3$ & $4 \cdot 3$ \\
\hline 796 & 40.5 & 26.0 & 10.0 & 0.7 & 2.0 & 3.0 & 3.8 & 4.9 & 4.9 \\
\hline 803 & $3^{8} .5$ & 24.5 & 10.0 & 0.7 & 2.0 & 3.2 & 4.1 & $4 \cdot 3$ & $4 \cdot 3$ \\
\hline 804 & 40.4 & 26.6 & 11.0 & 0.6 & 2.3 & $3 \cdot 7$ & 4.4 & 5.2 & 5.2 \\
\hline 808 & 39.0 & 24.5 & 10.2 & 0.6 & 2.3 & $3 \cdot 7$ & 4.5 & 5.2 & 5.2 \\
\hline 807 & 42.0 & 27.8 & 9.8 & 0.6 & 1.9 & 3.0 & 4.0 & 5.0 & 5.0 \\
\hline 834 & $41 \cdot \underline{5}$ & 26.0 & 10.0 & 0.6 & 2.1 & $3 \cdot 4$ & 3.8 & $4 \cdot I$ & 4.2 \\
\hline \multicolumn{3}{|c|}{ Average. } & 10.4 & 0.6 & 2.0 & 3.2 & 4.0 & 5.0 & 5.0 \\
\hline
\end{tabular}


TABLE 12-Series $s$

\begin{tabular}{|c|c|c|c|c|c|c|c|c|c|c|}
\hline $\begin{array}{l}\text { CAT. } \\
\text { No. }\end{array}$ & $\begin{array}{c}\text { BODY } \\
\text { LENGTH }\end{array}$ & $\begin{array}{c}\text { TAIL } \\
\text { LENGTH }\end{array}$ & $\begin{array}{c}\text { AMOUNT } \\
\text { REMOVED }\end{array}$ & $\begin{array}{c}3 \text { DAY } \\
\text { AMOUNT } \\
\text { REG. }\end{array}$ & $\begin{array}{c}6 \text { DAY } \\
\text { AMOUNT } \\
\text { REG. }\end{array}$ & $\begin{array}{c}9 \text { DAY } \\
\text { AMOUNT } \\
\text { REG. }\end{array}$ & $\begin{array}{c}\text { I2 DAY } \\
\text { AMOUNT } \\
\text { REG. }\end{array}$ & $\begin{array}{c}\text { I5 DAY } \\
\text { AMOUNT } \\
\text { REG. }\end{array}$ & $\begin{array}{c}\text { I8 DAY } \\
\text { AMOUNT } \\
\text { REG. }\end{array}$ & $\begin{array}{c}32 \text { DAY } \\
\text { AMOUNT } \\
\text { REG. }\end{array}$ \\
\hline 710 & 40.4 & 26.2 & 15.0 & 0 & 2.3 & 4.5 & 5.9 & 6.6 & 7.0 & 7.2 \\
\hline 714 & 39.0 & $24 \cdot 7$ & 14.5 & 0 & 2.3 & $5 \cdot 1$ & 6.3 & $7 \cdot 5$ & $7 \cdot 5$ & $7 \cdot 4$ \\
\hline 717 & 39.4 & 25.0 & 14.0 & 0 & 2.4 & 4.9 & 5.8 & 6.7 & 7.0 & 7.1 \\
\hline 724 & 43.0 & 27.8 & 14.7 & 0 & 2.4 & 5.0 & 6.3 & 6.8 & $7 \cdot 5$ & $7 \cdot 3$ \\
\hline 737 & 40.7 & $25 \cdot 3$ & 14.5 & 0 & $2 \cdot 3$ & 4.8 & 5.6 & 6.3 & $7 \cdot 1$ & $7 \cdot 1$ \\
\hline 739 & 42.0 & 27.0 & 14.4 & 0 & $2 \cdot 3$ & 4.4 & 4.6 & 5.0 & 6.2 & 6.4 \\
\hline $74^{\circ}$ & 41.0 & 26.8 & $\mathrm{I} 5.0$ & 0 & 2.4 & 5.0 & $5 \cdot 7$ & 6.0 & 6.9 & 6.9 \\
\hline $75^{\circ}$ & 42.5 & $27 \cdot 5$ & 15.0 & $\circ$ & 2.4 & $5 \cdot 1$ & 5.6 & 6.8 & 6.9 & 7.0 \\
\hline 757 & 37.2 & 25.0 & 14.0 & 0 & 2.3 & 4.6 & 5.6 & $7 \cdot 5$ & 7.2 & 7.2 \\
\hline $7^{6} \mathrm{I}$ & 40.4 & 27.2 & 15.2 & 0 & 2.4 & $5 \cdot 3$ & 5.9 & 6.8 & $7 \cdot 5$ & $7 \cdot 5$ \\
\hline $77 \circ$ & $41 \cdot 5$ & 27.0 & 15.0 & 0 & 2.4 & $4 \cdot 7$ & 5.6 & 6.7 & 7.2 & 7.2 \\
\hline 772 & 42.0 & 26.8 & 14.0 & 0 & 2.5 & 4.5 & 5.6 & 6.1 & 7.0 & 7.0 \\
\hline 774 & 43.0 & 28.0 & 14.5 & 0 & 2.4 & $4 \cdot 5$ & 5.8 & 6.5 & 6.7 & 6.8 \\
\hline 776 & $39 \cdot 4$ & 25.8 & 15.0 & o & 2.5 & $4 \cdot 5$ & 5.9 & 6.0 & 7.0 & 7.0 \\
\hline 785 & 39.5 & 25.6 & 15.0 & o & 2.5 & $4 \cdot 3$ & 4.9 & 6.8 & 6.8 & 6.8 \\
\hline 788 & 40.0 & $25 \cdot 3$ & 15.0 & o & 2.5 & 4.8 & 5.8 & 7.0 & 7.2 & 7.2 \\
\hline 793 & $3^{6.5}$ & 25.0 & 15.0 & o & 2.6 & 4.8 & 6.1 & 7.0 & $7 \cdot 4$ & 7.2 \\
\hline 794 & 39.0 & $25 \cdot 7$ & 14.8 & o & 2.5 & 5.0 & $5 \cdot 7$ & 7.7 & $7 \cdot 7$ & 7.2 \\
\hline 799 & $4 I \cdot 5$ & 26.5 & 15.0 & o & 2.5 & 4.8 & 6.0 & 6.9 & $7 \cdot 4$ & $7 \cdot 4$ \\
\hline 800 & $3^{8.4}$ & 24.0 & 15.5 & o & 2.8 & 5.0 & 6.0 & 6.7 & $7 \cdot 4$ & $7 \cdot 4$ \\
\hline \multicolumn{3}{|c|}{ Average. } & 14.8 & o & 2.4 & 4.9 & 5.8 & 6.7 & 7.2 & 7.2 \\
\hline
\end{tabular}

TABLE ${ }_{13}$-Experiment 4

\begin{tabular}{|c|c|c|c|c|c|c|c|c|c|c|c|c|c|c|c|}
\hline \multirow{2}{*}{ SERIES } & \multicolumn{2}{|c|}{3 DAY } & \multicolumn{2}{|c|}{$6 \mathrm{DAY}$} & \multicolumn{2}{|c|}{$9 \mathrm{DAY}$} & \multicolumn{2}{|c|}{ I 2 DAY } & \multicolumn{2}{|c|}{ I5 DAY } & \multicolumn{2}{|c|}{18 DAY } & \multicolumn{2}{|c|}{$3^{2}$ DAY } & \multirow{2}{*}{ 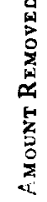 } \\
\hline & 岕 & 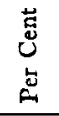 & $\begin{array}{l}\text { 泀 } \\
\text { 品 }\end{array}$ & 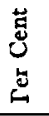 & $\begin{array}{l}\text { 岌 } \\
\text { 娄 }\end{array}$ & 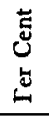 & $\begin{array}{l}\text { 泀 } \\
\text { 呈 }\end{array}$ & 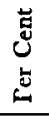 & $\begin{array}{l}\text { 范 } \\
\text { 怘 }\end{array}$ & 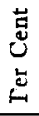 & 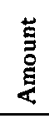 & 菢 & $\begin{array}{l}\ddot{g} \\
\stackrel{g}{\Xi}\end{array}$ & 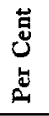 & \\
\hline Series O... & 0.4 & 13 & 1.0 & $3^{I}$ & I. 4 & 44 & I. 4 & 44 & 1.4 & 44 & I. 4 & 44 & I. 4 & 44 & 3.2 \\
\hline Series P... & 0.5 & Io & $1 \cdot 5$ & 29 & 2.0 & 40 & $2 \cdot 3$ & 44 & $2 \cdot 3$ & 44 & $2 \cdot 3$ & 44 & $2 \cdot 3$ & 44 & 5.2 \\
\hline Series R... & 0.6 & 6 & 2.0 & 20 & 3.2 & 31 & 4.0 & 40 & 5.0 & $4^{8}$ & 5.0 & $4^{8}$ & 5.0 & 48 & 10.4 \\
\hline Series S... & 0.0 & $\circ$ & 2.4 & I 6 & 4.9 & 33 & 5.8 & 39 & 6.7 & 45 & 7.2 & $4^{8}$ & 7.2 & $4^{8}$ & 14.8 \\
\hline
\end{tabular}


TABLE $\mathrm{J}_{4}$-Series $A A$ and $B B$

Series $A A$

\begin{tabular}{|c|c|c|c|c|c|c|c|}
\hline No. & $\begin{array}{c}\text { BODY } \\
\text { LENGTH }\end{array}$ & $\begin{array}{c}\text { TAIL } \\
\text { LENGTH }\end{array}$ & $\begin{array}{l}\text { AMOUNT } \\
\text { REMOVED }\end{array}$ & $\begin{array}{c}2 \text { DAY } \\
\text { AMOUNT } \\
\text { REG. }\end{array}$ & $\begin{array}{c}\text { S DAY } \\
\text { AMOUNT } \\
\text { REG. }\end{array}$ & $\begin{array}{c}7 \text { DAY } \\
\text { AMOUNT } \\
\text { REG. } \\
\end{array}$ & $\begin{array}{c}\text { IO DAY } \\
\text { AMOUNT } \\
\text { REG. }\end{array}$ \\
\hline & $m m$ & $m m$ & $m m$ & $m m$. & $m m$ & $m m$. & $m$. \\
\hline 900 & 19.0 & 11.0 & 2.3 & 0.8 & $1 \cdot 3$ & & \\
\hline 902 & 20.0 & 11.0 & 2.5 & 0.9 & I. 3 & & \\
\hline 904 & 19.0 & II.O & 2.5 & 0.8 & 1.2 & I. 3 & 1.3 \\
\hline 906 & 18.5 & 11.0 & 2.8 & 0.9 & I. 4 & 1.5 & 1.5 \\
\hline 908 & 21.0 & 12.0 & 3.0 & 0.8 & I. 3 & I. 4 & 1.5 \\
\hline 910 & 18.0 & 10.5 & 2.5 & 0.8 & I. 2 & 1.3 & 1.3 \\
\hline 912 & 20.0 & 12.0 & 2.8 & 0.9 & I. 4 & 1.5 & 1.5 \\
\hline 914 & 18.0 & 10.5 & 3.0 & 0.9 & & & \\
\hline 916 & 18.0 & 10.2 & 2.8 & 0.8 & 1.5 & & \\
\hline 918 & 18.0 & 10.5 & 2.7 & 0.8 & 1.5 & 1.5 & 1.5 \\
\hline 920 & 18.6 & II.0 & 2.8 & 0.8 & & & \\
\hline 922 & 18.0 & 10.5 & 2.6 & 0.8 & & & \\
\hline \multicolumn{3}{|c|}{ Average $\ldots, \ldots \ldots \ldots, \ldots \ldots \ldots$} & 2.6 & 0.8 & $1 \cdot 3$ & I.4 & 1.4 \\
\hline
\end{tabular}

Series $B B$

\begin{tabular}{l|l|l|l|l|l|l|l}
\hline 901 & 19.0 & 11.0 & 5.6 & I.2 & I.5 & & \\
903 & 19.0 & 10.5 & 5.4 & 1.2 & 2.5 & & \\
905 & 19.0 & 11.0 & 5.2 & 1.1 & 2.4 & 2.5 & 2.6 \\
907 & 19.5 & 12.0 & 6.2 & 1.2 & 2.6 & 3.2 & 3.5 \\
909 & 19.0 & 12.0 & 5.8 & 1.2 & 2.5 & 2.5 & 2.8 \\
911 & 18.2 & 11.2 & 6.2 & 1.1 & 2.6 & 3.1 & 3.4 \\
913 & 18.2 & 10.5 & 5.5 & 1.2 & 2.5 & 2.6 & 2.6 \\
915 & 20.0 & 11.8 & 6.1 & 1.2 & & & \\
917 & 18.5 & 10.6 & 5.4 & 1.3 & 2.4 & & \\
919 & 18.2 & 11.0 & 5.5 & 1.1 & 2.4 & 2.8 & 2.8 \\
921 & 19.0 & 11.0 & 5.7 & 1.2 & & & \\
923 & 18.2 & 10.6 & 5.2 & 1.1 & & & \\
\hline
\end{tabular}


TABLE 15-Series CC, Experiment 7

\begin{tabular}{l|c|c|c|c|c|c|c|c|c}
\hline NO. & $\begin{array}{c}\text { BODY } \\
\text { IENGTH }\end{array}$ & $\begin{array}{c}\text { TAIL } \\
\text { LENGTH }\end{array}$ & $\begin{array}{c}\text { AMOUNT } \\
\text { REMOVED }\end{array}$ & $\begin{array}{c}2 \text { DAY } \\
\text { REG. }\end{array}$ & $\begin{array}{c}3 \text { DAY } \\
\text { REG. }\end{array}$ & $\begin{array}{c}4 \text { DAY } \\
\text { REG. }\end{array}$ & $\begin{array}{c}5 \text { DAY } \\
\text { REG. }\end{array}$ & $\begin{array}{c}7 \text { DAY } \\
\text { REG. }\end{array}$ & $\begin{array}{c}12 \text { DAY } \\
\text { REG. }\end{array}$ \\
\hline & $m m$. & $m m$. & $m m$. & $m m$. & $m m$. & $m m$. & $m m$. & $m m$. & $m m$. \\
I036 & 29.2 & 19.0 & 5.5 & 0.7 & 1.4 & 1.8 & 2.3 & 2.8 & 2.8 \\
1039 & 28.2 & 16.2 & 6.0 & 0.7 & 1.6 & 1.9 & 2.3 & 2.9 & 2.9 \\
1040 & 26.5 & 17.0 & 5.0 & 0.8 & 1.5 & 1.8 & 1.8 & 2.4 & 2.4 \\
1043 & 31.2 & 21.0 & 5.2 & 0.8 & 1.6 & 1.8 & 2.3 & 2.7 & 2.7 \\
1044 & 31.0 & 19.0 & 6.0 & 0.7 & 1.6 & 1.9 & 2.2 & 2.6 & 2.6 \\
1047 & 30.0 & 19.2 & 5.0 & 0.7 & 1.4 & 1.8 & 2.1 & 2.6 & 2.6 \\
1049 & 27.5 & 17.3 & 5.0 & 0.7 & 1.5 & 1.9 & 2.3 & 2.6 & 2.6 \\
$105 I$ & 26.1 & 16.0 & 5.0 & 0.7 & 1.5 & 1.9 & 2.2 & 2.9 & 2.9 \\
1053 & 28.0 & 17.5 & 5.0 & 0.7 & 1.5 & 1.8 & 2.2 & 2.4 & 2.4 \\
\hline
\end{tabular}

There was measurable regeneration at the end of the first day (considered as $0.1 \mathrm{~mm}$.)

TABLE 16-Series $D D$, Experiment 7

\begin{tabular}{|c|c|c|c|c|c|c|c|c|c|}
\hline $\begin{array}{c}\text { BODY } \\
\text { LENGTH }\end{array}$ & $\begin{array}{c}\text { TAIL } \\
\text { LENGTH }\end{array}$ & $\begin{array}{l}\text { AMOUNT } \\
\text { REMOVED }\end{array}$ & $\begin{array}{c}2 \text { DAY } \\
\text { AMOUNT } \\
\text { REG. }\end{array}$ & $\begin{array}{c}3 \text { DAY } \\
\text { AMOUNT } \\
\text { REG. }\end{array}$ & $\begin{array}{c}4 \text { DAY } \\
\text { AMOUNT } \\
\text { REG. }\end{array}$ & $\begin{array}{c}5 \text { DAY } \\
\text { ANOUNT } \\
\text { REG. }\end{array}$ & $\begin{array}{c}7 \text { DAY } \\
\text { AMOUNT } \\
\text { REG. }\end{array}$ & $\begin{array}{l}\text { IO DAY } \\
\text { AMOUNT } \\
\text { REG. }\end{array}$ & $\begin{array}{c}12 \text { DAY } \\
\text { AMOUNT } \\
\text { REG. }\end{array}$ \\
\hline$m m$. & $m m$. & $\boldsymbol{m} \boldsymbol{m}$. & $\mathrm{mm}$. & $m m$. & $\mathrm{mm}$. & $m m$. & $\mathrm{mm}$. & $\mathrm{mm}$. & $\boldsymbol{m m}$. \\
\hline 26.2 & 16.2 & 10.0 & 0.9 & 2.6 & $3 \cdot I$ & 3.2 & 4.2 & 5.0 & 5.0 \\
\hline 32.0 & 20.2 & 10.0 & & 2.6 & 3.2 & $3 \cdot 5$ & $4 \cdot 3$ & 4.9 & 4.9 \\
\hline 27.2 & 17.2 & 10.0 & 1.0 & 2.4 & $3 \cdot 3$ & 3.9 & $4 \cdot 3$ & 5.0 & $5 \cdot c$ \\
\hline 32.0 & 21.0 & 10.2 & 1.0 & $2 \cdot 5$ & 3.2 & 3.8 & $4 \cdot 4$ & 4.8 & $4 \cdot 9$ \\
\hline 29.0 & 18.0 & 10.0 & 1.0 & 2.6 & $3 \cdot 2$ & 3.6 & $4 \cdot 1$ & 5.0 & 5.0 \\
\hline 28.2 & 17.0 & 9.8 & I.I & 2.5 & $3 \cdot 3$ & 3.6 & 4.4 & 5.1 & 5.1 \\
\hline 29.0 & 18.0 & 10.0 & 1.1 & 2.5 & $3 \cdot 4$ & $3 \cdot 7$ & $4 \cdot 1$ & 5.2 & 5.2 \\
\hline 27.0 & 17.0 & 9.9 & 0.9 & $2 \cdot 3$ & 3.1 & $3 \cdot 4$ & $4 \cdot 3$ & 4.9 & 4.9 \\
\hline $3 \mathrm{I} .0$ & 19.2 & 9.8 & 0.9 & 2.5 & $3 \cdot 3$ & $3 \cdot 7$ & $4 \cdot 1$ & $5 \cdot 3$ & $5 \cdot 3$ \\
\hline \multicolumn{2}{|c|}{ Averages ........ } & 9.9 & 1.0 & 2.5 & 3.2 & 3.6 & 4.2 & 5.0 & 5.0 \\
\hline
\end{tabular}


Amount of $\mathcal{T}$ ail Regenerated to Removed in Tadpoles 455

TABLE ${ }_{17}$-Averages Series $C C$ and $D D$ Experiment 7

\begin{tabular}{|c|c|c|c|c|c|c|c|c|c|c|c|c|c|c|c|c|c|}
\hline \multirow[b]{2}{*}{ BERIES } & \multirow[b]{2}{*}{ 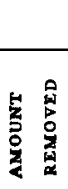 } & \multicolumn{2}{|c|}{ I DAY } & \multicolumn{2}{|c|}{2 DAY } & \multicolumn{2}{|c|}{3 DAY } & \multicolumn{2}{|c|}{4 DAY } & \multicolumn{2}{|c|}{5 DAY } & \multicolumn{2}{|c|}{7 DAY } & \multicolumn{2}{|c|}{ IO DAY } & \multicolumn{2}{|c|}{12 DAY } \\
\hline & & 荳 & 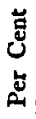 & 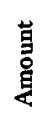 & 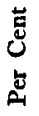 & 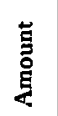 & $\begin{array}{l}\vec{U} \\
\dot{U} \\
\text { 岁 }\end{array}$ & 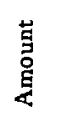 & 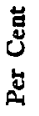 & $\begin{array}{l}\ddot{5} \\
\text { 总 }\end{array}$ & 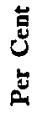 & $\begin{array}{l}\ddot{E} \\
\stackrel{0}{\mathrm{~g}}\end{array}$ & 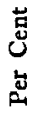 & 㟧 & 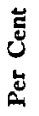 & $\begin{array}{l}\text { 葛 } \\
\stackrel{\Xi}{\Xi}\end{array}$ & 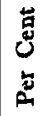 \\
\hline Series CC & $\begin{array}{l}m m . \\
5 \cdot 3\end{array}$ & $\begin{array}{c}m m . \\
0.1\end{array}$ & 2 & $\begin{array}{l}m m \\
0.7\end{array}$ & I 5 & $\begin{array}{l}m m . \\
\text { I. } 5\end{array}$ & 28 & $\begin{array}{c}m m . \\
\text { I. } 9\end{array}$ & 36 & $\begin{array}{c}m m \\
2.2\end{array}$ & $4 I$ & $\begin{array}{c}m m . \\
2.7\end{array}$ & 51 & $\begin{array}{c}m m . \\
2.7\end{array}$ & 51 & $\begin{array}{l}m m \\
2.7\end{array}$ & $5 I$ \\
\hline Series DD & 9.9 & 0 & 0 & 1.0 & 10 & 2.5 & 25 & 3.2 & $3^{2}$ & 3.6 & $3^{6}$ & 4.2 & 42 & 5.0 & 50 & 5.0 & 50 \\
\hline
\end{tabular}

TABLE 18-Series EE and FF, Experiment 8

\begin{tabular}{|c|c|c|c|c|c|c|c|c|c|c|c|c|c|c|c|c|c|}
\hline \multirow{2}{*}{ SERIES } & \multirow{2}{*}{ 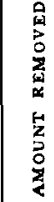 } & \multicolumn{2}{|c|}{3 DAY } & \multicolumn{2}{|c|}{$5 \mathrm{DAY}$} & \multicolumn{2}{|c|}{$6 \mathrm{DAY}$} & \multicolumn{2}{|c|}{8 DAY } & \multicolumn{2}{|c|}{12 DAY } & \multicolumn{2}{|c|}{ I5 DAY } & \multicolumn{2}{|c|}{$18 \mathrm{DAY}$} & \multicolumn{2}{|c|}{$21 \mathrm{DAY}$} \\
\hline & & $\begin{array}{l}\text { 节 } \\
\text { 总 }\end{array}$ & 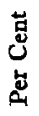 & $\begin{array}{l}\text { 葛 } \\
\text { 戛 }\end{array}$ & 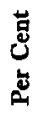 & $\begin{array}{l}\text { 䔽 } \\
\text { 曽 }\end{array}$ & $\begin{array}{l}\text { 嵓 } \\
\text { 岁 }\end{array}$ & $\begin{array}{l}\text { 荳 } \\
\text { 恶 }\end{array}$ & 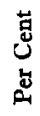 & 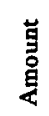 & 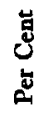 & $\begin{array}{l}\text { 岦 } \\
\text { 是 }\end{array}$ & 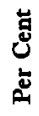 & $\begin{array}{l}\text { 壱 } \\
\text { 息 }\end{array}$ & 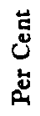 & 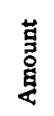 & 菢 \\
\hline Series EE & 5.1 & $\mathrm{~mm}$ & 25 & $\begin{array}{c}\mathrm{mm} \\
1.7\end{array}$ & 33 & $m m$. & 36 & $\begin{array}{l}m m \\
2.3\end{array}$ & 45 & $\begin{array}{c}\mathrm{mm} \\
2.3\end{array}$ & 45 & $\mathrm{~mm}$. & 45 & $m m$. & 45 & $m m$. & 45 \\
\hline Series FF & 10.2 & 1.9 & 18 & 2.9 & 29 & $3 \cdot 3$ & 33 & 3.6 & $3^{6}$ & 4.0 & 39 & $4 \cdot 3$ & 43 & 4.4 & 44 & 4.4 & 44 \\
\hline
\end{tabular}

